\title{
Farmers Integrated Management Challenges of Plantains product at Cauvery Delta, Thanjavur District
}

\author{
J.D.Aarthi Dhakshana, K.V.R.Rajandran
}

\begin{abstract}
In recent trends Farmers had been striving on farm management strategies to make their farming profitable. Farming activities are interdependent with various functions and strong inter-relations with production, finance and marketing. The Indian farmers were not acquainted with the modern management practices. Indian farmers plagued by various management challenges in their farming. However there is upward concern about the gap between the farmer's potential and their actual earnings. The farmers are not obtaining the profit for their hard work and challenges towards farming. This paper explores the integrated farming challenges of production, finance and marketing factors pertaining plantain product growers. The research area is Cauvery Delta, Thanjavur District. Convenient sampling technique method is used in collecting the data. The data obtained from 315 samples are investigated using descriptive statistics. The correlation tool was used to find out the relationship among the variables. The Multiple Regression tool was used to find out the probable variables that influence the factors. Then, the reliability test was employed to check the reliable of the collected data. The SPSS IBM 20 package was used for data analysis. The outcome of the research will facilitate the researchers, agricultural extension, government and farmers for the agricultural sustainable growth.
\end{abstract}

Index Terms: Agriculture, Farmers, Finance, Management, Marketing, Production.

\section{INTRODUCTION}

Agricultural Sustainable development is mainly focused to improve the farmer's profitability. The development of sustainable agriculture is essential (Jules Pretty, 2008; J.Whitehead 2016). Farmers can strengthen the agriculture sector by using the modern technology and innovation plans. In these recent years, Agriculture activities has been pressuring to the farmers to obtain better yield of product. The farmers are concern on resource utilization, social desires, energy, water and markets demands etc (De Vries, $\mathrm{M}$ and de Boer, I. J. M, 2010). Moreover moving towards sustainability causes some challenges in farming sector (P.Le Masson, B.Weil and A Hatchuel,, 2010). The agricultural challenges occurs in all the various inter connect activities of farming like production, financing and marketing. The challenges of farmers are to overcome the low level of production (J. Odra, B.I. Deng and G.P.Nhiem, 2004).

Revised Manuscript Received on July 05, 2019.

J.D.Aarthi Dhakshana, Department of Management Studies, Periyar Maniammai Institute of Science \& Technology, Thanjavur, India.

KVR Rajandran, Department of Management Studies, Periyar Maniammai Institute of Science \& Technology, Thanjavur, India.
Thus there is necessity to study the farmer challenges to prevent the agriculture and farmers from deteriorating farm activities. There are many research had undergone towards farming challenges but none of the study mention about the integrated challenges. This study focuses on production, financial and marketing challenges of the farmers. In this research the plantains is chosen as a product to study the farmer's challenges.

\section{LITERATURE REVIEW}

Holly Wang (2013) stated that Labour demand is adversely affected by the mechanization process. The researcher pointed that the production of flower, potato, groundnut, betel leaf, sesame and guava required high labour. The study revealed that the majority of the farmers faced labour scarcity as one of the challenge in production.

Yahaya and Stanley (2008) did research at Somntongo (Switzerland) regarding water scarcity. The researchers found that the water scarcity influence the production of crops. The inadequate water causes more livestock death in that region. Therefore the water scarcity had more influence on the production of agriculture crops and livestock's. In future scenario the marginal and small farmers will face more problems concerning of water (Mahendra Dev, 2012).

Khapayi and Celliers (2016) analyzed the farmer's technical knowledge and their productivity at South Africa. The researcher found that $57 \%$ farmers were not having experience and technical knowledge of mulching the crop. Consequently, the lack of technical knowledge affects the crop productivity.

Adepoju, Salman (2013) researched at Nigeria regarding to agricultural productivity. The researcher revealed that the $30 \%$ of the respondents were never had electricity supply. The researcher stated that the dynamic power supply affects the crop production. Therefore the electricity supply is one of the challengeable factors of agricultural production

Lawrence Abimah (2002) studied at Ghana about improving agriculture production. The researcher mentioned that many of the farmers were faced the problem of insufficient of money. Poor accessing of credit problem was faced by the small and marginal farmers.

Holly Wang (2013) stated as high cost of labour is the major challenging factor faced by the farmers in china. The researcher also pointed out that the many countries faced the problem of high labour cost. 
Quadri et.al (2013) analyzed the potato producer problems at Jammu. The researcher explored that the almost $60 \%$ of the farmers were agreed of high cost of seed was one of the problem. The seed was one of the basic inputs used for crop production.

Undutimi et.al (2013) described that the illiterate farmers are not maintained the record keeping. The lack of record keeping cause major challenges for financial management of farm towards profit.

Undutimi et.al (2013) researched on farmers direct marketing challenges at Thanjavur. The result of correlation between the direct selling challenges and lack of market information had highly correlated with significance level. Thus, lack of market information had some influence in marketing of agricultural products.

Lal et.al (2011) surveyed research at Bihar among potato farmers. The researcher explored that, the exploitation of middlemen was a major influenced challengeable factor among farmers. The farmers loss their bargaining power due to the exploitation of these middlemen.

Rout et.al (2013) researched from sugarcane producer at Orissa. The researcher revealed that the $62.5 \%$ of the farmers had faced the delay payment from the customer. The delay payment was one of the major problem in the studied area.

Baliyan and Kgathi (2009) studied the marketing problems of horticulture products at Botswana. The study revealed that the $19.49 \%$ of grower faced the problem of inadequate storage facility. Most of the crops were perishable in nature. Thus storage facility was basic necessity for farmers to safeguard their produce.

\section{RESEARCH METHODOLOGY}

This research study is a descriptive in nature. The researchers proposed both qualitative and quantitative methods. The study followed by primary data. The source of primary data employed from plantains farmers at Cauvery Delta region, Thanjavur District. The secondary data gathered from various e-books, journals, articles and relevant books. The sample population was undefined due to crop rotation practices followed by the farmers. Consequently, the convenient sampling technique from non-probability was followed. The sample size taken for this study was 315 . The well framed structured questionnaire tool was implemented to gather the data. The 5 point scale Likert method was followed in questionnaire. The research data be statistically analyzed using IBM SPSS20 (Statistical Package for Social Science) package. The statistics techniques pursued in this research was Reliability, Descriptive Statistics, Correlation and Multiple Linear Regression.

\section{A. Research Objectives:}

- To find the most influencing independent factor on plantains product management.

- To estimate the relationship between the agricultural product management and its management challenges faced by the plantains farmers.

- To indentify the highly impact factors on plantains product management of farmers.

\section{B. Variables under Investigation:}

Table-1: Describing Variables used in the Research

\begin{tabular}{|c|c|c|c|}
\hline & FACTORS & S.No & VARIABLES \\
\hline \multirow{12}{*}{ 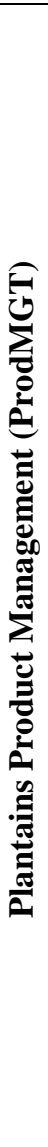 } & $\begin{array}{l}\text { Production } \\
\text { Challenges }\end{array}$ & 1 & Water Scarcity (PRO1) \\
\hline & & 2 & Electricity Scarcity (PRO2) \\
\hline & & 3 & $\begin{array}{l}\text { Poor Technical Knowledge } \\
(\mathrm{PRO} 3)\end{array}$ \\
\hline & & 4 & Labour Scarcity (PRO4) \\
\hline & $\begin{array}{l}\text { Financial } \\
\text { Challenges }\end{array}$ & 5 & $\begin{array}{l}\text { Lack of Record keeping } \\
\text { (FIN1) }\end{array}$ \\
\hline & & 6 & Lack of Credit (FIN2) \\
\hline & & 7 & High cost of inputs (FIN3) \\
\hline & & 8 & High Labour cost (FIN4) \\
\hline & $\begin{array}{l}\text { Marketing } \\
\text { Challenges }\end{array}$ & 9 & $\begin{array}{l}\text { Lack of Market Information } \\
\text { (MAR1) }\end{array}$ \\
\hline & & 10 & Inadequate Storage (MAR2) \\
\hline & & 11 & $\begin{array}{l}\text { Exploitation of Middlemen } \\
\text { (MAR3) }\end{array}$ \\
\hline & & 12 & $\begin{array}{l}\text { Delay in cash payment } \\
\text { (MAR4) }\end{array}$ \\
\hline
\end{tabular}

\section{RESULTS AND INTREPRETATION}

\section{A. Results of Reliability analysis:}

The Table-2, shows the reliability scale of the plantains product management (ProdMGT) dependent variable and independent factors (Production Challenges, Financial Challenges and Marketing Challenges)

Table-2

\begin{tabular}{|l|r|}
\hline Cronbach's Alpha & 0.98 \\
\hline N of items & 13 \\
\hline
\end{tabular}

The table-2of the cronbach's alpha value internal consistency was excellent of 0.982 . Therefore primary data of the study was well thought-out reliable. Nunnally (1978) suggested alpha value was considerable.

\section{B. Results of Descriptive:}

Table-3, show the result of descriptive Statistics of dependent variable (ProdMGT) and independent factors (Production Challenges, Financial Challenges and Marketing Challenges) 
Table-3

\begin{tabular}{|c|c|c|c|c|c|}
\hline Factors & $\begin{array}{l}\text { Variables } \\
\mathrm{N}=\mathbf{3 1 5}\end{array}$ & Mean & SD & $\begin{array}{l}\text { Averag } \\
\text { e } \square\end{array}$ & $\begin{array}{l}\text { Avera } \\
\text { e } \sigma\end{array}$ \\
\hline \multirow{4}{*}{$\begin{array}{l}\text { Production } \\
\text { Challenges } \\
\text { (Independent } \\
\text { Variable) }\end{array}$} & PRO1 & 4.67 & $\begin{array}{l}0.64 \\
2\end{array}$ & \multirow{4}{*}{4.67} & \multirow{4}{*}{0.65} \\
\hline & $\mathrm{PRO} 2$ & 4.69 & $\begin{array}{l}0.63 \\
2\end{array}$ & & \\
\hline & PRO3 & 4.68 & $\begin{array}{l}0.64 \\
1\end{array}$ & & \\
\hline & PRO4 & 4.65 & $\begin{array}{l}0.69 \\
1\end{array}$ & & \\
\hline \multirow{4}{*}{$\begin{array}{l}\text { Financial } \\
\text { Challenges } \\
\text { (Independent } \\
\text { Variable) }\end{array}$} & FIN1 & 4.71 & $\begin{array}{l}0.59 \\
4\end{array}$ & \multirow{4}{*}{4.67} & \multirow{4}{*}{0.64} \\
\hline & FIN2 & 4.66 & $\begin{array}{l}0.65 \\
5\end{array}$ & & \\
\hline & FIN3 & 4.64 & $\begin{array}{l}0.66 \\
9\end{array}$ & & \\
\hline & FIN4 & 4.68 & $\begin{array}{l}0.62 \\
6\end{array}$ & & \\
\hline \multirow{4}{*}{$\begin{array}{l}\text { Marketing } \\
\text { Challenges } \\
\text { (Independent } \\
\text { Variable) }\end{array}$} & MAR1 & 4.71 & $\begin{array}{l}0.59 \\
3\end{array}$ & \multirow{4}{*}{4.66} & \multirow{4}{*}{0.65} \\
\hline & MAR2 & 4.65 & $\begin{array}{l}0.68 \\
2\end{array}$ & & \\
\hline & MAR3 & 4.64 & $\begin{array}{l}0.68 \\
8\end{array}$ & & \\
\hline & MAR4 & 4.65 & $\begin{array}{l}0.65 \\
6\end{array}$ & & \\
\hline
\end{tabular}

As to determine the mean and standard deviation for the dependent and independent variable the descriptive statistics tool was used. The table-3 shows that the average means 4.67 and average standard deviations 0.65 for production challenges. 4.67 mean, 0.64 standard deviation; 4.66 mean and 0.65 standard deviation for financial challenges and marketing challenges respectively. The result reveals that almost three factors influence fairly.

\section{Results of Correlation:}

Table-4 shows the Correlation results for dependent variable (ProdMGT) and independent factors (Production Challenges, Financial Challenges and Marketing Challenges).

Table-4

\begin{tabular}{|c|c|c|}
\hline \multicolumn{1}{|c|}{ Table-4 } & $\begin{array}{c}\text { Pearson } \\
\text { Correlation }\end{array}$ & P-Value \\
\hline PRO1 & $.779 * *$ & 0.000 \\
\hline PRO2 & $.892^{* *}$ & 0.000 \\
\hline PRO3 & $.894 * *$ & 0.000 \\
\hline PRO4 & $.691 * *$ & 0.000 \\
\hline FIN1 & $.926^{* *}$ & 0.000 \\
\hline FIN2 & $.831^{* *}$ & 0.000 \\
\hline FIN3 & $.792^{* *}$ & 0.000 \\
\hline
\end{tabular}

\begin{tabular}{|c|c|c|}
\hline FIN4 & $.834^{* *}$ & 0.000 \\
\hline MAR1 & $.845^{* *}$ & 0.000 \\
\hline MAR2 & $.782^{* *}$ & 0.000 \\
\hline MAR3 & $.708^{* *}$ & 0.000 \\
\hline MAR4 & $.825^{* *}$ & 0.000 \\
\hline
\end{tabular}

The table- 4 indicates the bivariate correlation among the variables. The result shows that the relationship among variables, i.e ProdMGT (dependent variable) with PRO1, PRO2, PRO3, PRO4, FIN1, FIN2, FIN3, FIN4, MAR1, MAR2, MAR3 and MAR4 (Independent Variables) were correlated with highly significantly P-Value. Further the coefficient $r$ value of PRO1 0.779, 0.892, 0.894, 0.691, 0.926, $0.831,0.792,0.834,0.845,0.782,0.708,0.825$ followed by PRO2, PRO3, PRO4, FIN1, FIN2, FIN3, FIN4, MAR1, MAR2, MAR3 and MAR4 respectively. Therefore, all independent variables are positively correlated with the dependent variables.

\section{Results of Multiple Linear Regression}

Table-4 shows the summary model result for dependent variables (ProdMGT) and independent factors (Production Challenges, Financial Challenges and Marketing Challenges)

Table-5

\begin{tabular}{|l|r|}
\hline \multicolumn{2}{|c|}{ Summary Model } \\
\hline $\mathrm{R}$ & 0.950 \\
\hline R Square & 0.903 \\
\hline Adjusted R Square & 0.899 \\
\hline $\begin{array}{l}\text { Standard Error of } \\
\text { the Estimate }\end{array}$ & 0.2 \\
\hline
\end{tabular}

The table-5 showed the model summary of regression analysis in which adjusted $\mathrm{R}^{2}$ explain how much the plantains product management influence on three challengeable factors. The adjusted $\mathrm{R}^{2}$ value $(0.903)$ showed that $95 \%$ influence the plantains product management.

Table-6 shows the ANOVA results for dependent variable (ProdMGT) and independent factors (Production Challenges, Financial Challenges and Marketing Challenges)

Table-6

\begin{tabular}{|c|c|c|c|}
\hline \multicolumn{4}{|c|}{ ANOVA } \\
\hline & Regression & Residuals & Total \\
\hline $\begin{array}{l}\text { Sum of } \\
\text { squares }\end{array}$ & 111.82 & 12.066 & $\begin{array}{r}123.88 \\
6\end{array}$ \\
\hline Df & 12 & 302 & 314 \\
\hline $\begin{array}{l}\text { mean } \\
\text { square }\end{array}$ & 9.318 & & \\
\hline
\end{tabular}




\begin{tabular}{|l|r|r|r|} 
F & 233.228 & & \\
\hline P-value & 0.000 & & \\
\hline
\end{tabular}

The ANOVA table-6 explains with the significance $(<0.05) \mathrm{F}=233.228$ that the predictors independent variables has strong prediction over the dependent variable. A multiple linear regression was calculated to predict plantains product management challenges based on their production challenges, financial challenges and marketing challenges. A significant regression equation was found $(\mathrm{F}(12,302)=233.228$, $\mathrm{p}<.000$, with an $\mathrm{R}^{2}$ of 0.903 .

Table-7 shows the Regression Coefficient results of dependent variable (ProdMGT) and independent factors (Production Challenges, Financial Challenges and Marketing Challenges).

Table-7

\begin{tabular}{|l|c|c|c|c|c|}
\hline \multicolumn{7}{|c|}{ Coefficients } \\
\hline $\begin{array}{c}\text { Variabl } \\
\text { es }\end{array}$ & B & $\begin{array}{c}\text { Standar } \\
\text { d Error }\end{array}$ & Beta & T & Sig \\
\hline $\begin{array}{l}\text { Consta } \\
\text { nt }\end{array}$ & 0.017 & 0.094 & & 0.178 & 0.859 \\
\hline PRO1 & -0.124 & 0.050 & -0.127 & -2.476 & 0.014 \\
\hline PRO2 & -0.300 & 0.120 & -0.302 & -2.506 & 0.013 \\
\hline PRO3 & 0.480 & 0.100 & 0.489 & 4.798 & 0.000 \\
\hline PRO4 & 0.074 & 0.064 & 0.081 & 1.147 & 0.252 \\
\hline FIN1 & 0.727 & 0.079 & 0.688 & 9.248 & 0.000 \\
\hline FIN2 & 0.107 & 0.070 & 0.111 & 1.537 & 0.125 \\
\hline FIN3 & 0.248 & 0.039 & 0.264 & 6.322 & 0.000 \\
\hline FIN4 & 0.203 & 0.061 & 0.202 & 3.303 & 0.001 \\
\hline MAR1 & -0.118 & 0.068 & -0.112 & -1.746 & 0.082 \\
\hline MAR2 & -0.154 & 0.050 & -0.167 & -3.097 & 0.002 \\
\hline MAR3 & -0.187 & 0.070 & -0.205 & -2.671 & 0.008 \\
\hline MAR4 & 0.048 & 0.045 & 0.050 & 1.061 & 0.290 \\
\hline
\end{tabular}

As to study the consequence of the independent variable the multiple regressions were used.

$(\mathrm{X} 1=\mathrm{PRO} 1, \mathrm{X} 2=\mathrm{PRO} 2, \mathrm{X} 3=\mathrm{PRO} 3, \mathrm{X} 4=\mathrm{PRO} 4, \mathrm{X} 5=$ FIN1, X6 = FIN2, X7 = FIN3, X8 = FIN4, X9 = MAR1, X10 $=$ MAR2, X11 = MAR3, X12 = MAR4) to dependent variable $(\mathrm{Y}=$ ProdMGT $)$.

ProdMGT $=0.017+(-0.124)(\mathrm{PRO} 1)+(-0.300)(\mathrm{PRO} 2)+$ $0.428(\mathrm{PRO} 3)+0.074(\mathrm{PRO} 4)+0.727(\mathrm{FIN} 1)+0.107$ $($ FIN2 $)+0.248($ FIN3 $)+0.203($ FIN4 $)+(-0.118)($ MAR1 $)+$ $(-0.154)($ MAR2 $)+(-0.187)($ MAR3 $)+0.048($ MAR4 $)$.

Regression equation shows the impact of dependent variable on predictors. It shows that how the challenges influence the plantain product management. From the table-7 reveals the PRO1 P-value is 0.014 (significant). The value of independent variable of PRO1 is increased by 1 unit than there would be a decrease in dependent variable i.e. ProdMGT by -0.124 units. This shows that there is a significance relationship with negative impact of PRO1 on ProdMGT. The table 7 shows that the PRO2 P-Value is 0.013 (significant). The value of independent variable of PRO2 is increased by 1 unit than there would be a decrease in dependent variable i.e. ProdMGT by -0.300 units. This shows that there is a significance relationship with negative impact of PRO2 on ProdMGT. The table 7 shows that the PRO3 $\mathrm{P}$-Value is 0.000 (highly significant). Then the value of independent variable of PRO3 is increased by 1 unit than there would also increase in dependent variable i.e. ProdMGT by 0.480 units. This shows that there is a strong significance relationship with positive impact of PRO3 on ProdMGT. The table 7 reveal that the P-Value of PRO4 B value $=0.074$ with 0.252 i.e. greater than 0.05 . Thus the PRO4 has no significant relationship with PRO4 on ProdMGT.

The table 7 explore that the FIN1 P-value is 0.000 (highly significant). The value of independent variable of FIN1 is increased by 1 unit than there would be increase in dependent variable i.e. ProdMGT by 0.727 units. This shows that there is a significance relationship with positive impact of FIN1 on ProdMGT. The FIN2 P-Value is 0.125 which has no significant relationship with the $\mathrm{B}$ value $=0.107$. This shows that there is no significance relationship with FIN2 on ProdMGT. The FIN3 P-Value is 0.000 (highly significant). The value of independent variable of FIN 3 is increased by 1 unit than there would be increase in dependent variable i.e. ProdMGT by 0.248 units. This shows that there is a significance relationship with positive impact of FIN3 on ProdMGT. The table 7 explore that the FIN4 P-Value is 0.001 (highly significant). The value of independent variable of FIN4 is increased by 1 unit than there would be increase in dependent variable i.e. ProdMGT by 0.203 units. The results indicate that there is a significance relationship with positive impact of FIN4 on ProdMGT.

The table 7 reveals that the MAR1 P-Value is 0.082 which has no significant relationship with the $\mathrm{B}$ value $=-0.118$. This shows that there is no significance relationship with MAR1 on ProdMGT. The P-Value of MAR2 is 0.002 (Significant). The value of independent variable of MAR2 is increased by 1 unit than there would be a decrease in dependent variable i.e. ProdMGT by -0.154 units. This shows that there is a significance relationship with negative impact of MAR2 on ProdMGT. The P-Value of MAR3 is 0.002 (Significant). The value of independent variable of MAR3 is increased by 1 unit than there would be a decrease in dependent variable i.e. ProdMGT by -0.187 units. This shows that there is a significance relationship with negative impact of MAR3 on ProdMGT. The table 7 explores that the MAR4 P-Value is 0.290 which has no significant relationship with the $\mathrm{B}$ value $=$ -0.048 . This shows that there is no significance relationship with MAR4 on ProdMGT.

\section{DISCUSSION ON FINDINGS}

A. Objective 1: To find the most influencing independent factor on plantains product management.

The researcher found that the plantains product management influence by three challengeable factors. The descriptive statistics was used to find out the mean value of the three factors (Production Challenges, Financial Challenges and Marketing Challenges). The result revealed that the 4.67 average mean and 0.65 average standard deviation of production challenges influence major on plantains product management. The 4.67 average mean and 0.64 
average standard deviation of financial challenges concerned second influence factor and followed by 0.46 average mean value and 0.65 average standard deviation of marketing challenges as a third factor influence the plantain product management.

B. Objective 2: To estimate the relationship between the agricultural product management and its management challenges faced by the plantains farmers.

The researcher did the correlation statistics analysis for this above objective. The table- 4 result revealed that the dependent and independent variables were highly correlated with $>.6$ Pearson's coefficient value. Hence the result reveals that the relationship between the dependent and independent variables is strong. FIN1 (Poor Record Keeping) independent variables has high correlated value of 0.926 with the dependent variable.

C. Objective 3: To indentify the highly impact factors on plantains product management of farmers.

The researcher used multiple linear regression technique to find out the most influencing factor. The table-7 regression coefficient revealed that PRO1, PRO2, PRO3 were the influencing factor of plantains product management with highly significant P-value. The result explored that FIN1 (Lack of Record Keeping) has high impact, followed by FIN3 (High cost of inputs), PRO3 (Lack of Technical Knowledge), FIN4 (High Labour Cost), PRO1 (Water Scarcity), PRO2 (Electricity Scarcity), MAR3 (Middlemen Exploitation), MAR2 (Inadequate Storage) respectively. Thus the research objectives were proved statistically.

\section{CONCLUSION}

The researcher found the prominent influencing factor of plantains product management in the study area. The influence factors such as production, financial and marketing challenges of the plantain product. The result of the research will help the farmers to know their status of predominant challenges in managing the plantain products. The outcomes of the research will also facilitate the agriculture extensions, agriculture researcher and government for introducing or revamping new policy towards sustainable development of agricultural sector.

\section{REFERENCES}

1. A.A.Adepoju, K.K.Salman, "Increasing Agricultural Productivity through Rural Infrastructure: Evidence from Oyo and Osun States, Nigeria", International Journal of Applied Agriculture and Apiculture Research, vol. 19(1 -2), 2013, pp.1 -10.

2. Arun Makal, Abhradip Banerjee, Avik Roy, Suman Hazra and Krishnendu Polley, "Issues and Problems in Agricultural Development: A Study on the Farmers of West Bengal. Development among the Tribal and Minority Societies", 2017, pp.179 -189.

3. B.Lal, Sinha, T.K., Kumar, Anil, Pandit, and Pandey, N.K. "Constraints perceived by the farmers in adoption of potato technology" Potato Journal, vol. 38(1), 2011, pp.73-77.

4. De Vries, M and de Boer, I. J. M, "Comparing environmental impacts for livestock products: a review of life cycle assessments ”, Livest. Sci, vol. 128, 2010, pp.1-11

5. Holly Wang, "Agricultural risks and risk management in the current context of Chinese economy", Agricultural Finance Review Emerald, vol. 73, 2013, pp. 245-254.

6. J. Odra, B.I. Deng and G.P.Nhiem, "Framework for Rehabilitation and Development of Post-War South Sudan", Khartoum (Sudan): University of Bahr el Ghazal, 2004.
7. J.D.Aarthi Dhakshana, K.V.R.Rajandran, "A Study on Challenges Faced by the Farmers in Direct Marketing, the Rural Business Series", Indian Journal of Science and Research, vol.14 (1), 2017, pp. 91-97.

8. J.L.Nunnally, "Psychometric Theory. New York: McGraw Hill Company", 1978.

9. J.Whitehead, "Prioritizing Sustainability Indicators: Using Materiality Analysis to Guide Sustainability Assessment and Strategy. Business Strategy and the Environment" 2016, pp. 1-14.

10. Jules Pretty, "Agricultural sustainability: concepts, principles and evidence", Philos Trans R Soc Lond B Biol Sci, vol. 363(1491), 2008, pp.447-465.

11. Lawrence Abimah, "Improving Agricultural Production in Ghana; A Case Study of Extension Education for Migrant Farmers in Awudome Communities in the Volta Region", Submitted to the University of Ghana, in Partial Fulfillment of the Requirements for the award of Master of Arts Degree in Adult Education (2002).

12. M.I.Khapayi, P.R.II, Celliers (2016), "Factors limiting and preventing emerging farmers to progress to commercial agricultural farming in the King William's Town area of the Eastern Cape Province, South Africa", South African Journal of Agricultural Extension, vol.44(1), 2016, pp.1-17

13. P.Le Masson, B.Weil and A Hatchuel, "Strategic Management of Design and Innovation", Cambridge University Press, Cambridge, (2010)

14. P.Le Masson, B.Weil, A.Hatchuel and P.Cogez, "Why aren't they locked in Waiting Games? Unlocking Rules and the Ecology of Concepts in the Semiconductor Industry". Technol Anal Strateg, vol. 24 (6), 2012, pp. 617-630.

15. Quadri Javeed Ahmad Peer, S.K.Kher, Nafees Ahmad, M.H Chesti, J S Manhas, Satesh Kumar and Bhavana Gupta, "An Analysis of Reasons of Non- adoption of Selecting different crop production practices by potato growers in Sub-Tropics of Jammu Division", IJSR International Journal of Scientific Research, vol 2(6), 2013,pp. 9-11.

16. R.K. Rout, R.K. Mishra, Narayan Bar and Debabrata Mondal, "Farmers Perception on Contract Farming of Sugarcane in Orissa: A Village Level Study", Economic Affairs, vol 58(4), 2013, pp. 367-371.

17. S.Mahendra Dev, "Small farmers in India: Challenges and opportunities" Indira Gandhi Institute of Development Research, Mumbai, 2012, pp. 1-35.

18. S.P. Baliyan and D.L. Kgathi, "Production and marketing problems in small scale horticultural farming in Botswana", Proc. XVIth IS on Hort. Econ. \& Manag. Ed.: P.P. Oppenheim Acta Hort. 831, ISHS, 2009 , pp. $31-40$.

19. Undutimi Johnny Dudafai, Niger Delta University, Nigeria, "Record Keeping Among Small Farmers in Nigeria: Problems and Prospects", International Journal of Scientific Research in Education, Vol. 6(2), 2013, pp. 214-220.

20. Yahaya Mijinyawa and Stanley S'manga Dlamini, "Impact assessment of water scarcity at Somntongo in the low yield region of Swaziland", Scientific Research and Essay, vol 3(2), 2008, pp. 061-065. 